\title{
ASEAN ECONOMIC COMMUNITY IMPLEMENTATION AND INDONESIAN TEXTILE INDUSTRY COMPETITIVENESS 1
}

\author{
Yuvensius Sri Susilo \\ Faculty of Economics \\ Universitas Atma Jaya Yogyakarta \\ e-mail: yssusilo@gmail.com
}

\begin{abstract}
This study aims to analyze the impact of ASEAN Economic Community implementation in 2015 on the competitiveness of Indonesian textile and textile products industry. It uses simulations with the GTAP model to answer the proposed research questions. The GTAP simulation results suggest that Indonesian textile industry would gain the largest trade surplus followed by Thailand and Malaysia. For apparel, Vietnam would benefit the most, followed by Indonesia and Thailand. The ratio of domestic to import prices analysis suggests that Indonesian textile products have higher competitiveness than the other ASEAN's. For the apparel products, Indonesia is as competitive as both Malaysia and the Philippines.
\end{abstract}

Keywords: AEC 2015, Competitiveness, Textile dan Textile Products Industry, Indonesia JEL Classification: C68, F15

DOI: http://dx.doi.org/10.20885/ejem.vol5.iss2.art5

\begin{abstract}
Abstrak
Penelitian ini bertujuan untuk menganalisis dampak penerapan Masyarakat Ekonomi ASEAN pada 2015 pada daya saing industri tekstil dan produk tekstil Indonesia. Alat analisis yang digunakan deskriptif dan simulasi dengan model GTAP. Hasil simulasi GTAP menyarankan bahwa industri tekstil Indonesia akan memperoleh surplus perdagangan terbesar, diikuti oleh Thailand dan Malaysia. Untuk produk pakaian, Vietnam memperoleh manfaat terbesar diikuti Indonesia dan Thailand. Berdasarkan rasio harga domestik terhadap harga impor, daya saing produk tekstil Indonesia relatif lebih tinggi dibandingkan negara-negara ASEAN lainnya. Untuk produk pakaian, Indonesia kompetitif, sejajar dengan Malaysia dan Filipina.
\end{abstract}

Kata kunci: AEC 2015, Daya Saing, Tekstil dan Produk Tekstil

JEL Classification: C68, F15

\section{INTRODUCTION}

The implementation of ASEAN Economic Community (AEC) will kick off in 2015. AEC materialized from the desire of

\footnotetext{
${ }^{1}$ Summarized from the research funded by the Central Board of ISEI, 2012-2015, in the framework of the XVI Plenary Session in Edinburgh 2013. The author wishes to thank Prof. Dr. Herman Siregar (IPB), Prof. Dr. Tulus Tambunan (Usakti), and Prof. Dr. Lincolin Arsyad (UGM) for their comments and suggestions on the research report draft, but responsibility for the contents of the paper remains on the author.
}

ASEAN to create ASEAN economies into a solid region and took into account in the international economic arena. The cconomic integration applied to AEC is not an economic integration as adopted by the EU (European Union) which imposed a single currency (Euro). In AEC the objectives are the free flow of goods, services and skilled labor, as well as a freer flow of investment (Ministry of Trade, 2009). In the implementation AEC will have 12 priority sectors, namely fisheries, e-travel, e-ASEAN, 
automotive, logistics, wood-based industries, rubber-based industries, furniture, food and beverages, footwear, textile and textile products, and health (Central Bank of Indonesia, 2012).

Lately, the debate especially among academics and policy makers about the readiness or ability of national industries to compete in the domestic market during the later enactment of the ASEAN Economic Community (AEC) by 2015 are more fierce. With the enactment of the 2015 AEC, at least fitting to its purpose, ASEAN would become a single market, which means that all goods and services from other ASEAN members will gain 100 percent freedom of entry into Indonesian domestic markets (Tambunan, 2013b). The plan of implementation of the AEC in 2015 at its core is no longer barriers to the flow of goods and services, people and capital between member countries of ASEAN (Tambunan, 2013a).

Indonesian goods and services are completely free to access the countries in the ASEAN region and vice versa. Furthermore, the matter which becomes a serious problem now and in the future is whether the national industry is capable of producing goods that are not only able to compete with similar goods produced in other ASEAN countries which entered the domestic market, but also able to penetrate the markets in other member states.

One of the industry groups which has become one of the Indonesian reliable non-oil export products is textile and textile products (TPT) industry. TPT industry is one of the Indonesian industry pioneers and manufacturing backbone. The strategic position of the industry is increasingly apparent when viewed from the side of its contribution to the economy, especially in the form of export earnings and employment. Even if looking at a period of about 20 years ago the development of the textile industry's performance indicated its golden age, in which the industry was able to con- tribute more than $35 \%$ of total manufacturing exports and the biggest job creation in the manufacturing sector (Ministry of Industry, 2011).

The TPT industry is expected to remain a major contributor to the Indonesian economy in the future. One of the main reasons is that Indonesia still has a comparative advantage for labor-intensive industries and a large domestic market, due to the country's population of 240 million inhabitants. In 2012, Indonesia is ranked 12th in the world for the export of textiles, with a world market share of approximately 1.6\%. During the period of 2005 and 2007, rapid growth was influenced by changes in the market structure in the United States and the European Union, which imposed a quota seat on many textile products and apparels from China. Since 2008, due to the weak global economic situation, the number of factories, exports, and production has been reduced. Then in the year 2011, in line with the gradual global economic trends itshowed signs of the opposite.

TPT industry in Indonesia is important considering that most of the companies in this industry group are coming from the category of micro, small and medium enterprises (SMEs). Conceivably if the Indonesian TPT industry could not compete with similar products from countries other ASEAN members, there would be a lot of SMEs moving towards collapse as a consequence of: (1) unemployment, and (2) increased poverty, and (3) income foreign exchange from the export of textile being reduced. The importance of the TPT industry in the macro economy is also supported by Hermawan (2011). The study stated that the TPT industry contributes in increasing employment and foreign exchange earnings.

The question that arises then is how will the opportunities and challenges for the Indonesian TPT industry, with the enactment of the AEC or the ASEAN single market in 2015 be? More concretely, 
are the products of the domestic TPT industry able to penetrate the market in the other ASEAN member countries? On the other hand, are they able to survive and dominate the domestic market when faced with invasion of similar products from other ASEAN member countries?

Indonesian TPT products competitive ability relates to the competitiveness of the product or TPT industry. In the Ministerial Regulation No. 41 Year 2007 on the Standard Process, it is stated that: "Competitiveness is the ability to show results better, faster, or more meaningful". It means thatPermendiknas No. 41 of 2007 include s: (1) the ability to strengthen its market position, (2) the ability to connect with the environment, (3) the ability to improve performance without stopping, and (4) ability to enforce a favorable position. According to Porter (1998), competitiveness covers the country's competitiveness, the company/industry's competitiveness, and product competitiveness.

Competitiveness is the ability of a commodity to enter foreign markets and the ability to survive in the market, in the sense that if a product is competitive, the product is exactly in demand. Judging from the presence of the advantages in competitiveness, the competitive advantage of a commodity are classified into two types, namely natural advantage and the acquired advantage.

How is the competitiveness of Indonesian TPT industry? The emergence of newly industrialized countries engaged in the TPT industry put a strong enough pressure on the ability of the market penetration of Indonesian exports in major countries. Based on data from the Agency for the Assessment Policy, Climate and Industrial Quality (BPKIMI) known in 2012, it is a decline in exports of TPT goods of $5.24 \%$ over the previous year (Sari, 2013). On the other hand, on average in the period 20062012 it is an increase in exports of goods amounted to $5.44 \%$ of the TPT industry with a value of USD 12,459,967,000.

Associated with the development of the TPT industry, the Ministry of Industry Republic of Indonesia will and have to develop and enhance the competitiveness of TPT industry. The move was done through the revitalization program of technical service units (UPT) textile machine through procurement assistance, provision of textile machinery and equipment as well as technical training for human resources (HR) industry. Through development and improvement program of the competitiveness of the textile industry, the TPT industry is expected to grow 6.52 percent in 2014 and to absorb the labor of 216.00 people per year from 2013 to 2014 (Rini, 2013).

A serious problem faced today and in the future is whether the national industry is able to produce items that are not only able to compete with similar goods made in other ASEAN countries which entered the domestic market. On the other side it is also able to penetrate markets in other ASEAN member countries.

An industry group which is one of the Indonesia's reliable non-oil export products is textile and textile products industry (TPT). The Indonesian TPT industry became more important considering that most of the companies in this industry group is from the category of micro, small and medium enterprises (SMEs). When the Indonesian TPT industry cannot compete with similar products from other ASEAN member countries, many SMEs will be stopping production with consequent increase in unemployment and poverty and reduced foreign exchange earnings from the export of textile. Based on the description that has been submitted, the question in this research is how is the impact of the implementation of AEC 2015 on the competitiveness of Indonesian TPT industry?

A study conducted by Akatiga and Fes (2007) found that after the expiration of the agreement of textile and apparel (ATC) 
which abolished quotas and the conditions of granting quotas for Chinese products to the United States Indonesia has a significant ability to compete in the global market. The ability to compete will still be able to be achieved if barriers in the domestic industry can be significantly reduced. In fact, Indonesian textile exports rose faster than the rate of world exports and in the first half of 2006, an increase took place in the value of exports and market expansion. Macro analysis showed that low industrial growth after the crisis was mainly caused by the low capital investment that affected the productivity of the industry. In addition, there are indications that there has been a shift in the industry towards the downstream apparel and textile industry fading. Macro analysis also shows that in the past without quota textile export performance is not affected significantly, but more likely because of restrictions on Chinese products. Thus, the low industrial growth and competitiveness concerns in international trade is not resulted by the expiration of the ATC, but rather is caused by problems in the domestic supply side.

Sutarta (2001) in a study analyzes the impact of the elimination of the Multi Fibre Arrangement (MFA) on the Indonesian economy, and other textile and clothing exporting countries which are in Asia (Malaysia, Philiphina, Thailand, Vietnam, China, a group of New Industrial State (NIEs, and a group of South Asian Countries) as a comparison. The impact of changes in the elimination of MFA on changes in some economic variables such as the level of welfare, GDP, terms of trade, trade patterns, output and demand factor endowment predicted using general equilibrium model of multi-state and multisector, or known as the GTAP (Global Trade Analysis Project) model. Simulation results show that in general, Indonesia would benefit from the elimination of MFA, although the benefits received by the Indonesian economy are relatively small. In comparison, the economic benefits received by Indonesia, among the countries analyzed, are the relatively small. In general, countries that would benefit a relatively large economies are China and South Asian countries group. Almost all of the countries analyzed in this study will receive economic benefits, not only Vietnamese who would benefit from the elimination of this MFA.

\section{METHODS}

The type of data required in this study is based on secondary data source. Secondary data were collected related to (1) the volume of production, (2) the volume/value of exports, and (3) the volume/value of imports. The information to be collected related to the study are: (1) the constraints faced by the textile industry, and (2) any policy which can be done by the government and the business community to improve the performance and competitiveness of the textile industry. Sources of data and information are obtained from the Central Statistics Agency (BPS), the Indonesian Textile Association (API), Indonesia Investment Coordination Board, the Ministry of Industry and Trade Ministry.

The simulations use the GTAP Model Version 8, assuming that each state removes tariffs when importing textile products originating from AEC countries. This simulation uses the initial equilibrium based on the input-output table in 2004 and 2007. For the purposes of analysis, the textile sector in the simulation is divided into two, namely Textile products and Apparel. Separation of these products aims to obtain a more in-depth analysis of the results for each of these products.

\section{GTAP Model Framework of Many Countries' Open Economy}

The core of the GTAP model is extracted from Brockimeier (1996) and Hertel (1997) which states that the GTAP (Global Trade 
Analysis Project) is applied general equilibrium model of many countries which includes activities of the world economy covering 57 industry sectors and 129 composite regions which is an aggregation of 229 countries. Nevertheless, the standard theory used for the formation of the GTAP model is similar to that used in applied general equilibrium models. Since so many components in the formation of the GTAP model is so complex, it is not easy to get the basic idea of the theory behind the GTAP model.

Presentation of the GTAP model in an open economy of many countries can be explained with the help of Figure 1. Because the GTAP model is covered 57 sectors and covers 129 countries and 45 territories composition, then to simplify it, except for one country, other countries covered in the sector are put together the rest of the world (ROW) (Narayanan et al., 2012). One such country is further used to indicate a change in the structure of the model used to develop models of the open economy. Framework equilibrium GTAP model to an open economy will be explaned with the help of Figure 1 below.

The starting point in the exposition of the GTAP model starts from the household associated regional as a country or set of countries (regions). Based on per capita Cobb Douglas utility function, the household income is spent in the form of regional final demand, namely: household consumer expenditure (PRIVEXP), government spending (GOVEX) and saving (SAVE). This approach represents a standard framework (standard closures), with each component of final demand having a constant contribution to regional income. Thus, the increase in regional income will result in a proportional change in household consumer expenditure, government and savings. Another alternative government spending (GOVEX), saving (SAVE) are both considered to be exogenous so that consumer household income is calculated as a residual. Regional household income is derived from the value of the output level agent (VOA) that is paid by the manufacturer as a consideration for the use of resources (endowment commodities).

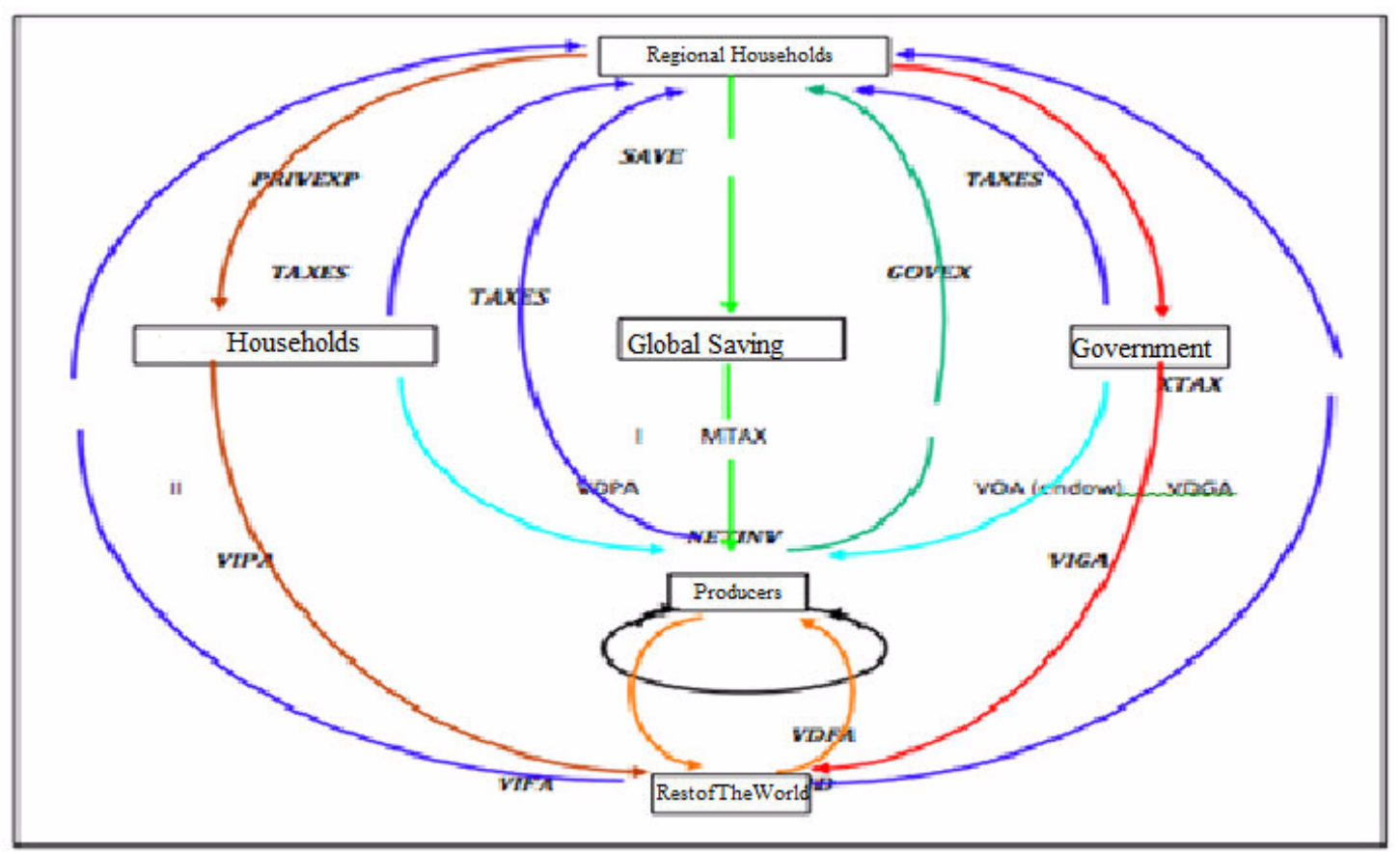

Source: Narayanan et al. (2012)

Figure 1: GTAP Model in an Open Economy 
The amount of government revenue is spent entirely consumer goods declared as Value of Domestic Government Spending (VDGA). In order to incorporating the government's behavior into the model, the subutility function of Cobb Douglas is used in the GTAP model. Thus the assumption of a constant budget share can be applied to the model.

The second component of final demand is household consumers. Household consumers spend all of their income on consumer goods, which is expressed as the value of Household Consumer Expenditure in the Interior (VDPA). Household optimization behavior of consumers is also incorporated into the GTAP by applying the function CDE (Constan Difference Elasticity).

Savings as a third component of final demand entirely are used for investment (NETINV). In the GTAP model of investment it is due to the saving (-driven). Due to these assumptions, ongoing investment (current investment) is not incorporated into the model during the observation period so it does not affect the ability of the production industries in the model.

On the production side, Figure III.1 shows that the producer receives a payment from the sale of consumer goods to household consumers (VDPA) and government (VDGA), between the inputs to other producers (VDFA) and investment goods sector savings (NETINV). Assuming zero profit, these revenues are used entirely to purchase intermediate inputs (VDFA) and primary production factors (VOA).

The Company received additional income from the sale of commodities to the rest of the world. Exports are expressed with VXMD. But on the other hand, manufacturers are now using their income not only for the primary production factors and intermediate inputs produced in the country, but also to import intermediate inputs (VIFA). In addition, the company also had to pay a consumption tax on imported inputs from regional households, this component into the TAXES component.
GTAP model uses the Armington assumption in the trade sector which makes it possible to distinguish imports by country of origin and explains intra-industry trade of the same product. Thus, based on these assumptions the heterogeneity of goods is distinguished also by country of origin of the goods. The different types of goods not only by sector but also are based in each sector (within each sector), depending on whether the goods are produced domestically or imported. Based on this assumption, the imported goods are assumed to separate from goods produced domestically. The elasticity of substitution of inputs is in all uses. Under these conditions, then the company decides where it should import sources based on a combination of a variety of imported commodity prices. The company then determines the combination of imported goods and domestic.

Figure 1 also shows the relationship of the components of final demand accounting in an open economy. Government spending and household consumer goods not only for domestic consumption but also imported goods are shown by symbols (VIPA and Viga).

The GTAP model also included government intervention. Government intervention is in the form of taxes and subsidies. Flow taxes and subsidies hereinafter stated net tax flow with TAXES. Aliaran tax revenues (TAXES) derived household consumers, government and regional firms to households. From the government side, TAXES consist of consumption tax on commodities produced by the economy. Meanwhile TAXES paid by household consumers include consumption and income taxes (net of subsidies). In an open economy model of government domestic and private households have to pay an additional tax of imported commodities to households so that the regional component of the tax to be paid by the government and the private sector is also included in the equation in the consumption tax and expenditure on consumption of imported goods. 
Analogous to the behavior of a company that has been discussed, many countries enter the GTAP model equations demand for commodities imported by the government and household consumers. Commodities imported and domestic commodities combined in a composite nest for household consumers and government. The elasticity of substitution between imported goods and domestic in the composite nest of the utility function is assumed to be the same. Import demand equation by firms and households differ only in donations imports.

The third component of the relationship equation is the final demand savings. Because change is hard savings component depicted in Figure 1, the savings component reduces to the global savings (GLOBAL Savings). In the GTAP model, savings and investment are calculated globally so that all savers in the model face the same commodity price savings. This means that if all other markets in many countries in the model is in equilibrium, all firms will receive zero profits and all households are at prohibitive costs, the global investment must equal global savings and Walras Law is fulfilled.

Finally, we arrive at the equation's residual component. Based on Figure 1 rest of the world obtain payment from the sale of goods to household consumers, government and corporate. This acceptance will then be spent on export goods from a single country (countries that are not included in the rest of the world are expressed by VXMD), import taxes, MTAX, XTAX export tax paid to the regional household.

\section{GTAP Simulation Model}

GTAP model is a Computable General Equilibrium (CGE) model developed by scientists Thomas Hertel and his colleagues at the Center for Global Trade Analysis, Department of Agricultural Economics, Purdue University, Indiana (Hertel, 1997). Unlike the standard CGE models designed to simulate the impact of a policy (shock) of the state, the GTAP model is designed for many countries. GTAP is designed to simulate the impact or effect of a policy change (shock) in some countries or some sectors of some countries or some sectors (Sutarta, 2001).

There are three main components in the GTAP model. The first is the GTAP model framework, which was developed on the basis of the regional economy to describe the activity and behavior of domestic companies (firms), consumer households (Households) and domestic government (government). This section describes the input-output structure linking several industrial sectors existing in the model simultaneously in a chain starting from the value-added primary products (primary goods) to process the goods (intermediate goods) and ends at the final consumption goods (final consumer goods) for household consumers and government. The second major component is the GTAP database. This section contains a database of the economic matrix of bilateral trade, transport, and protection of each of the countries concerned. This database is derived from input-output tables for each country. The third component of the GTAP is a behavioral parameter, which contains four parameters: the elasticity of substitution (consumption and production), the elasticity of transformation that will determine the degree of intersectoral mobility and flexibility of regional investment allocation of primary factors, and elasticity of consumer demand.

In this research, the simulation is done with Computable General Equilibrium (CGE) Model applications employ the Global Trade Analysis Project (GTAP) version 8 that is multiregional CGE model of the world economy and trade. This model is a comparative static models that can be used to measure the impact of international trade. Existing data in the GTAP Database version 8 uses the initial equilibrium in 2007 Database version 8 including 57 sectors and 129 countries (Narayanan et al., 2012). Howev- 
er, these data can be aggregated in accordance with the objectives of the study.

In accordance with the research objectives, the research will be used in the data aggregation countries that joined the AEC Indonesia, Malaysia, Philiphina, Thailand, Vietnam, Singapore, Cambodia, and Laos. The sectoral aggregation uses the aggregation of three sectors, namely Textiles (TEX), clothing or wearing apparel (WAP), and wool and silk or wool and silk cocoons (WOL).

This scenario should be used to avoid various errors baseline setting. The simulation results uses the GTAP model, the amount of change produces very dependent variables and is sensitive to the magnitude of the shock defined as a simulation scenario. Furthermore, this research will focus on estimating the implications of the policy (shock) in the form of trade liberalization between ASEAN countries within the framework of the implementation of the AEC. Policy (shock) will be in the form of tariff elimination Textile products (TEX), clothing or wearing apparel (WAP), and wool and silk or wool and silk cocoons (WOL) to zero throughout the AEC members.

Based on the shock that has been done then the economic impact would be seen throughout the AEC members. As will be analyzed from the results of the policy simulations are changes to variable terms of trade (terms of trade) simulated industry, labor demand, exports, trade balance, value added, output, changes in GDP and welfare received by residents AEC member countries.

\section{RESULTS AND DISCUSSION}

The Impact of AEC on Changes in Textile and Apparel Trade Balance in AEC Member Countries.
Based on the simulation results shown that the implementation of AEC 2015 to the textile sector trade balance resulted in different effects for TPT in each country (Table 1). Indonesia (IDN) will gain the greatest benefit from the trading of textile products, followed by Thailand (THA) and Malaysia (MYS). Countries that experienced the most trade deficit of textile are Vietnam (VNM) followed by Cambodia (KHM) and Philipines (PHL).

Simulation results for apparel products give different results when compared with textile products. For apparel, the liberalization of the trade surplus will give the largest apparel to Vietnam and Indonesia, Thailand, Philipines, Malaysia and Cambodia. Deficit countries are Laos (LAO) and Singapore (SGP).

In the case of the textile industry, Vietnam, Laos and Cambodia textile trade balance deficit because these countries in developing a ready-made apparel industry import textile raw material mainly from Indonesia and Thailand (Fry, 2010). This condition is consistent with the simulation results showing the trade balance textiles Indonesia and Thailand experienced a relatively large surplus among other countries. For apparel, Vietnam enjoyed a relatively large surplus among the countries due to AEC members of the apparel industry in several member states to move AEC readymade apparel factories to Vietnam. It is the impact of an increase in the cost of production in the apparel industry, such as labor costs are expensive (Fry, 2010). Such conditions are experienced by Malaysia and Indonesia because of the pressure of expensive labor costs for manufacturing the apparels, and many companies are moving their factories to Vietnam.

Table 1: The Impact of AEC on Changes in Textile and Apparel Trade Balance in AEC Member Countries (Million USD)

\begin{tabular}{rrrrrrrrr}
\hline Product & KHM & \multicolumn{1}{c}{ IDN } & \multicolumn{1}{c}{ LAO } & MYS & \multicolumn{1}{c}{ PHL } & \multicolumn{1}{c}{ SGP } & \multicolumn{1}{c}{ THA } & \multicolumn{1}{c}{ VNM } \\
\hline & -278.39 & 967.82 & -0.22 & 227.27 & -276.29 & 40.59 & 579.66 & -3485.77 \\
& 516.20 & 1891.98 & -25.63 & 931.30 & 1204.76 & -18.23 & 1802.97 & 8209.51 \\
\hline
\end{tabular}


The Impact of Textile and Textile Products Liberalization in AEC on the Improvement of AEC Member Countries's Welfare

Vietnam will be affected by the increase in the welfare of the greatest of the liberalization of the textile industry trade between AEC countries (Table 2). Indonesia will receive welfare benefits increase of \$ 361 million. However, this number is relatively small when compared with the increase in welfare benefits received by Vietnam of US $\$ 862.08$ million. From all member countries of the AEC, only Laos which will decrease the level of welfare of $\$ 11.5$ million. Laos experienced a trade deficit for both the textile and apparel industry (Table 1).

The Impact of Textile and Textile Products Liberalization in the AEC to the Change of Textile and Textile Products Output in AEC Member States
Liberalization of trade in textile and apparel industry in the AEC framework will increase the production of textiles and apparel in Vietnam that is relatively higher compared to countries other AEC members. For textile products, after Vietnam, the countries whose textile production respectively also increases are Malaysia, Thailand and Indonesia. This illustrates that the liberalization of the textile sector will improve the competitiveness of Vietnam compared to other AEC members. Indonesia's total production placed in the rearmost ranks, indicating that the competitiveness of Indonesian textile industry declined as a result of the liberalization policy. Relatively the same condition also occurs in the apparel industry; Vietnam will produce apparel in the relative amounts of the highest among member countries other AEC (Table 3).

Table 2: The Impact of Textile and Textile Products Liberalization in AEC on the Improvement of AEC Member Countries' Welfare (Million USD)

\begin{tabular}{ccccccccc}
\hline & KHM & IDN & LAO & MYS & PHL & SGP & THA & VNM \\
\hline Value & 10.05 & 361.43 & -11.50 & 114.97 & 148.14 & 47.69 & 471.58 & 862.08 \\
\hline
\end{tabular}

Table 3. The Impact of Textile and Textile Products Liberalization in the AEC to the Change of Textile and Textile Products Output in AEC Member Countries

\begin{tabular}{lcllllllr}
\hline Product & KHM & IDN & LAO & MYS & PHL & \multicolumn{1}{c}{ SGP } & THA & \multicolumn{1}{c}{ VNM } \\
\hline Textile & -7.46 & 18.56 & -14.59 & 39.49 & 19.05 & 0.86 & 19.35 & 82.72 \\
Apparel & 27.69 & 42.28 & -17.53 & 78.09 & 37.06 & -5.66 & 26.32 & 232.37 \\
\hline
\end{tabular}

Table 4. The Impact of Textile and Textile Products Liberalization in the AEC to the Value Added Textile Industry in AEC Member Countries

\begin{tabular}{lcccccccc}
\hline Product & KHM & IDN & LAO & MYS & PHL & SGP & THA & VNM \\
\hline Textile & -7.46 & 18.56 & -14.59 & 39.49 & 19.05 & 0.86 & 19.35 & 82.72 \\
Apparel & 27.69 & 42.28 & -17.53 & 78.09 & 37.06 & -5.66 & 26.32 & 232.37 \\
\hline
\end{tabular}

Table 5: The Impact of AEC TPT Liberalization on Price Ratio Price to Domestic Textile Imports in the AEC Member Countries

\begin{tabular}{lrrrrrrrr}
\hline Product & KHM & IDN & LAO & MYS & PHL & SGP & THA & VNM \\
\hline Textile & 0.14 & 0.07 & 0.07 & 0.11 & 0.06 & 0.01 & 0.18 & 0.21 \\
Apparel & 0.33 & 0.12 & 0.13 & 0.12 & 0.13 & 0.01 & 0.34 & 0.28 \\
\hline
\end{tabular}


The Impact of Textile and Textile Products Liberalization in the AEC to Value Added Textile Industry in AEC Member Countries

The impact of liberalization of trade in textiles and apparel to the value-added textile and apparel industry (Table 4) caused Vietnam to obtain the greatest value added among other AEC countries, both in the textile and apparel industry. Even the added value obtained for Vietnamese apparel industry amounted to 232.37 far exceeds the added value received by Indonesia which only amounted to 42.28 .

The simulation results illustrate if Vietnam will enjoy the greatest added value when the textile and apparel industry is liberalized in the framework of the implementation of AECs.

The Impact of Textile and Textile Products Liberalization in the AEC on Domestic Price Ratio to Textile and Textile Products Import Price in the AEC Member Countries

The impact of TPT liberalization on the TPT domestic price ratio on TPT import prices in the AEC member countries (Table 5) shows that if the value of the ratio of small mean level of price competitiveness of the domestic textile has a relatively high when compared with the price of textile imports, and vice versa if the ratio is greater value means the price level of the domestic textile competitiveness is low when compared to the price of imported textile.

In Table IV.5 seen that the Indonesian textile industry is relatively competitive prices when compared with countries other MEA members. Indonesia has a domestic prices ratio to import prices of textiles as of 0.07 . A country which also has a great price competitiveness is Philiphines, with a ratio value of 0.06 . Vietnam actually has the greatest value of the ratio that is equal to 0.21 and then followed by Thailand and Malaysia. The country that has the highest price competitiveness is Singapore with a ratio value of 0.01 .

For the apparel industry, Indonesia also has a high competitiveness in line with Malaysia, Laos and the Philipines. Countries with the price competitiveness of the lowest finished garments are Cambodia Thailand and Vietnam. Singapore remans the country's competitiveness highest price finished garments such as the textile industry.

\section{The Impact of TPT Liberalization to the TPT Export Price of AEC Member Countries}

In the textile industry, Vietnam will be a country that will gain the highest export price decline to other AEC member countries. In other words, Vietnamese textile products enjoy the highest price declines in the AEC countries' market. This will result in Vietnamese textile products becoming increasingly competitive among other AEC member countries. Other countries that will enjoy a decrease in export prices of textile products that is relatively high after consecutive Vietnam are Laos, Malaysia, Thailand and Indonesia. A country that received the lowest export price reduction is Singapore.

Vietnam will also enjoy a reduction in the price of apparel exports the most. Other countries are also gaining huge drop in export prices, although not as big as Vietnam, respectively are Malaysia, Laos, Thailand, and Laos. Indonesia was the country that received the lowest export price decline among other AEC members countries (Table 6).

Table 6. The Impact of TPT Liberalization to the TPT Export Price of AEC Member Countries

\begin{tabular}{lcccccccc}
\hline Product & KHM & IDN & LAO & MYS & PHL & SGP & THA & VNM \\
\hline Textile & -0.75 & -1.66 & -3.50 & -3.39 & -1.17 & -0.04 & -2.50 & -8.72 \\
Apparel & -2.47 & -0.62 & -3.61 & -5.18 & -2.20 & -0.82 & -2.82 & -13.69 \\
\hline
\end{tabular}




\section{Indonesian Textile and Textile Products (TPT)}

TPT industry is a form of modern manufacturing industry first built in the early process of industrialization in Indonesia. In the global level, Indonesia can be late in developing the modern TPT industry. However, the TPT industry plays a critical role in the early stages of the industrialization of the countries in the world such as in the UK, North America, Japan, Hong Kong Korea, Taiwan, and the ASEAN countries and China.

The development of the TPT industry in East and Southeast Asia is strongly associated with the development of the TPT industry in Japan (Indonesian Investment Coordiation Board, 2011). These relationships are seen in the activities of Foreign Direct Investment (FDI) in the Japanese TPT industry in the countries of East Asia and Southeast Asia. In the period of 1955-1974, the countries of East Asia and ASEAN each absorb $40 \%$ and $28 \%$ of the total Japanese investment in the textile sector. The number of Japanese investment projects in the textile sector increased significantly after the mid 1960s until 1974 when Japan lost its comparative advantage due to increased labor costs and labor shortages. This forced the Japanese TPT industry to move its TPT industry to countries with lower wages such as in Indonesia and make Indonesia as a production base for export.

Historically, Indonesian TPT industry is the relocation from East Asia through the process of international trade and FDI. FDI in the textile sector in the years 19601990's is mostly from Japan and South Korea (Indonesia Investment Coordination Board, 2011). In the 1990s the value of Japan and South Korea's foreign investment when combined reached more than $50 \%$ of the total FDI engaged in the textile in Indonesia. Consequently, these two FDI give significant impact on the development of the TPT industry in Indonesia.

For Japanese FDI, most companies engaged in mid-stream segment, especially for knitting, followed by refinement of thread and weaving. Besides the many segments of the garment also attract Japanese investors. Instead South Korea FDI during 1990-1998 was concentrated in the garment segment (downstream sector). In addition to investing in the garment, South Korea FDI is also distributed in the central sector such as weaving, knitting and finished textile. In that period there was only one South Korean company that invested in the spinning segment. Both Japan and South Korea FDI are less interested in investing in the upstream sector.

Modernization of the TPT industry in Indonesia is marked by the entry of FDI into this sector. Indonesian TPT industry experienced several phases of development. When divided into several stages of industrialization, the development of the TPT industry can be divided into several phases namely the introduction phase, the phase of import substitution and export phase.

Shown in Figure 2, structure and characteristics of textiles and textile products (TPT) in Indonesia is divided into three parts. In the upper part there is the manufacturer of natural fiber and fiber making. The upstream industry is capital intensive, large-scale industry, fully automatic technology, the number of workers is small but large output per worker and very large energy absorption. Products produced are: (1) Natural Fiber such as Cotton, (2) Man-Made Fibers, namely Synthetic Fiber (Polyester, Acrylic, Nylon), and Rayon Fiber (Viscose).

In the middle there is the spinning, weaving, knitting, dyeing, printing, and finishing industry. The nature of the industry is semi-intensive capital, and large-scale industry, which uses modern technology and continues to grow; employment is greater than the upstream sector, and also large energy absorption. Products crafted are: (1) Yarn derived from: natural fibers, artificial fibers, and mixtures, (2) Fabrics that are Grey cloth (Blace), finished fabrics, knit fabrics, and non-woven fabrics. 


\begin{tabular}{|c|c|c|c|}
\hline 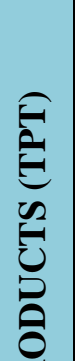 & $\begin{array}{c}\text { UP } \\
\text { STREAM }\end{array}$ & $\begin{aligned} \rightarrow & \text { Natural Fiber } \\
\rightarrow & \text { Fiber Making } \\
& \text { (Man-Made } \\
& \text { Fiber) }\end{aligned}$ & $\begin{array}{l}\text { - Capital intensive, and large-scale industry } \\
\text { - Full automatic technology } \\
\text { - The number of workers is small but large output per } \\
\text { worker } \\
\text { - Very large energy absorption } \\
\text { - Products are: (1) Natural Fiber such as Cotton, (2) } \\
\text { Man-Made Fibers, namely Synthetic Fiber (Polyester, } \\
\text { Acrylic, Nylon), and Rayon Fiber (Viscose) }\end{array}$ \\
\hline 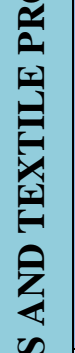 & $\begin{array}{c}\text { MID } \\
\text { STREAM }\end{array}$ & $\begin{aligned} \overrightarrow{ } & \text { Spinning } \\
& \rightarrow \text { Weaving } \\
& \rightarrow \text { Kinitting } \\
\rightarrow & \text { Dyeing, Print- } \\
& \text { ing, } \\
& \text { Finishing }\end{aligned}$ & $\begin{array}{l}\text { - Semi-intensive capital, and large-scale industry } \\
\text { - Modern technology and continue to grow } \\
\text { - Employment is greater than the upstream sector } \\
\text { - Large energy absorption } \\
\text { - Products are: (1) Yarn derived from: natural fibers, } \\
\text { artificial fibers, and mixtures, (2) Fabrics that are } \\
\text { Grey cloth (Blace), finished fabrics, knit fabrics, and } \\
\text { non-woven fabrics. }\end{array}$ \\
\hline 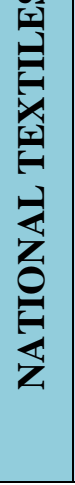 & $\begin{array}{c}\text { DOWN } \\
\text { STREAM }\end{array}$ & $\begin{array}{l}\text { Garment } \\
\text { Other Textiles } \\
\text { Product }\end{array}$ & $\begin{array}{l}\text { - Labor intensive, the majority of them are women } \\
\text { - The turnover is fast acting } \\
\text { - Supporting technology industry is always evolving, } \\
\text { up to date, and combined with the labor-intensive and } \\
\text { capital-intensive } \\
\text { - Products are: (1) Garment/Clothing, (2) Household } \\
\text { Textiles such as Bed Linen, Table Linen, Cushion } \\
\text { Cover, Toilet Linen, Kitchen Linen, Curtains, Car- } \\
\text { pets, Tents, and others, (3) Industrial Supplies for the } \\
\text { seat (motorcycle and car seat cover), Army, Hospital, } \\
\text { and others. }\end{array}$ \\
\hline
\end{tabular}

Figure 2. Structure and Characteristics of Indonesian TPT Industry

Source: Susanto (2013)

There is a company on the downstream garment and other textile products. The nature of the industry is labor intensive, the majority of them are women, the turnover is fast acting, supporting technology industry is always evolving, up to date, and combined with the labor-intensive and capital-intensive. Products produced are: (1) Garment/Clothing, (2) Household Textiles such as Bed Linen, Table Linen, $\mathrm{Cu}$ shion Cover, Toilet Linen, Kitchen Linen, Curtains, Carpets, Tents, and others, (3) Industrial Supplies for the seat (motorcycle and car seat cover), Army, Hospital, and others.

\section{Problems in Indonesian TPT Industry}

From a variety of secondary sources, the problems faced by the TPT industry in Indonesia led to the internal and external problems as follows (API, 2013; Ministry of Industry, 2013, and Susanto, 2013). (i) TPT, footwear and leather tanning industry still have a lot of challenges due to the dominant use of old machines that were aged over 20 years. Older machines in addition to causing huge energy consumption also cause the less or lower speed and quality of the product. Competition will be intense with the emergence of a new competitor countries that adopted advanced technology. (ii) There is uncertainty of the business environment, both external and internal, causing the TPT industry always in a situation of national anxiety and pressure uncertainties. (iii) For working capital financing. Until now the provision of working capital financing solutions has not been comprehensively. (iv) Energy. Sources of internal problems that are classical and latent, to 
dwell on the pricing and supply of energy (electricity, fuel, gas, and coal). (v) Rates of transport infrastructure and logistics (land, sea, and air) are expensive.

The next problem is: (vi) Human Resources. Skilled labors are still lacking so this impacts on productivity performance. (vii) Imported products. The domestic market is still flooded with imported textile products, ranging from raw materials to finished products. $98 \%$ cotton raw material for the needs of national textile industry depends on imports. (viii) The financial crisis in the USA and Europe. The economic downturn leads trade of textile products to a drop in demand and prices. This is an external problem that disrupts the lives of the textile industry of the country. (ix) The role of government in improving competitiveness is still not optimal, especially in terms of provision of infrastructure, ease of financing, energy availability, and ease rules on imported raw materials. (x) In addition to external factors and other classical problems in the country that affect the performance of the national textile industry, prior to heading 2015 other challenge is the political factor. In 2013 and 2014 is a political year, and this is definitely going to confront and affect the activity of the national textile industry. Proven on the date of the Provincial Minimum Wage, 2013, the government in its determination gave the interests of the political moment priority attention and tended to listen to the voice of bipartite and tripartite outside agencies. In other words, the government ignored the two employment-his work partner institutions.

\section{The Constraints of Indonesian TPT In- dustry}

Constraints faced by Indonesian TPT industry to meet the AEC 2015 are the constraints on the internal side and external side. Constraints on the internal side covered (API, 2013, Indonesia Investment Coordination Board, 2011, Susanto, 2013): (i) lack of capital and access to financing sources, (ii) limitations of technology and most of the machines on aging, (iii) human resource productivity is relatively low, (iv) the continuity of supply of raw materials and dependence on imported raw materials, and (v) the ability to market products, especially for small-scale producers and medium textile. Further constraints on the external aspect consist of: (i) the unfavorable business climate in some cases due to the lack of government policies supporting performance (production and distribution) textile industry, (ii) the price of energy (electricity, LPG, and fuel) are likely to increase, (iii) labor costs increased significantly, without offset by the increase in skill and productivity, (iv) tariffs and expensive transportation infrastructure, (v) the influx of imported textile products, and (vi) the world economic crisis which led to decreased export demand.

\section{Competitiveness of Indonesian TPT In- dustry in ASEAN}

Figure 3 reveals Indonesian product comparison with some other ASEAN countries (API, 2013, Indonesia Investment Coordination Board, 2011, Susanto, 2013). There, it appears that (1) Textile fiber industry (silk HS 50, wool HS 51, cotton HS 52 and other vegetable fibers tesktil HS 53) of Indonesia is relatively undeveloped compared with the industry of other ASEAN countries; (2) For products of artificial staple fibers (HS 55) and man-made filament, strip and the like of artificial textile materials (HS 54), Indonesia has the highest competitiveness compared to other ASEAN textile manufacturers, and Thailand are competitors; and (3) For textile or apparel products (HS 61 and HS 62), Indonesia is far behind from Vietnam, while Cambodia began to increase its exports, and this is a serious threat. 


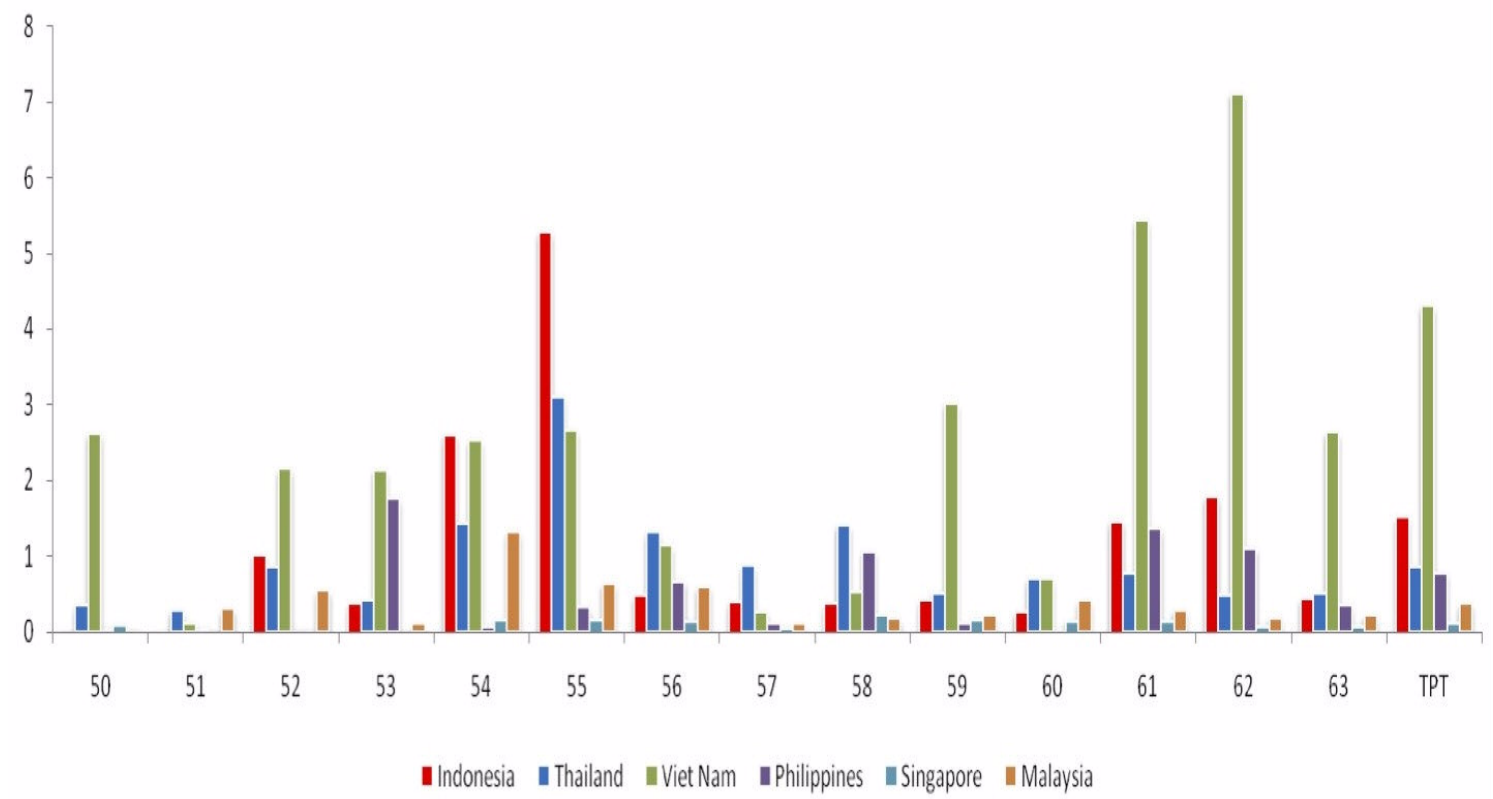

Figure 3. The Competitiveness of Indonesian Textile Products in ASEAN Source: Susanto (2013)

Indonesia still has the creative potential of the textile-based culture, the traditional textiles/handicrafts (batik, ikat, songket, embroidery, embroidery, jumputan, and other kinds) which are a wealth of local ethnic and scattered throughout the Indonesian archipelago with all forms of beauty, uniqueness, philosophy, rich in motifs and techniques into the process and be able to present a fashion product. Epecia 1ly for batik, Indonesia should maintain and cap batik (batik using wax materials/malam) and should limit the production of printing batik as do other countries, say China and Malaysia. Categories of textile products with the ethnic or cultural characteristics have unique dynamics that are not owned by the same type of products in other ASEAN countries. The uniqueness and the dynamics of the product are a competitive advantage and at the same time to develop.

\section{CONCLUSION}

Simulation results show that the Indonesian TPT industry, for certain products, is still able to compete with similar products in the ASEAN region. Application of AEC in
2015 makes a threat and an opportunity for the Indonesian TPT industry. One of the emerging threat is the possible use of instruments allowed by the World Trade Organization (WTO), as Anti-Dumping, Safeguard, and Anti-Subsidies by export destination countries of Indonesian textile products as a way to protect the domestic market of the country concerned. Then one of the opportunities is imported from extraASEAN dominated by textile products (fibers, yarns, fabrics and other finished textile products) and it can be charged by the Indonesian TPT industry that is complete for among the ASEAN countries.

ASEAN's total population reached over 600 million people and this is a promising market, not only for Indonesia but also for other countries outside ASEAN. Thus, to meet the ASEAN Economic Community (AEC) in 2015 the main businesses in the strengthening of the national TPT industry that has to be done by the Indonesian government with the reform in the country are, namely: (i) Trade policy and industrial policy synergy and mutual support. The end goal is for the protection of the domestic market and the strengthening 
of the domestic textile manufacturers. (ii) Coordination among ministries in the government in an effort to create a conducive business environment with the goal ultimately is to increase the competitiveness of the national TPT products. (iii) Cooperation with the government of the national TPT industry, in the form of APIs involved, both for discussion and to control the implementation of its policies.

AEC 2015 to face not only the national TPT industry, but it is the scope of the country. In this case it is no longer facing the textile industry of Vietnam or the textile industry of Thailand, Malaysia, and others, but facing the country of Vietnam or Thailand, Malaysia, and other ASEAN countries. Therefore, in order to meet AEC 2015, the most important thing is the role and support of the Indonesian government to the national TPT industry to: (i) Increasing the competitiveness of the national TPT products, particularly in the production and distribution. (ii) The policy is conducive, especially on fiscal, labor, energy, and the domestic market. (iii) The policy for the provision of human resources in textile sector experts to sustain the growth of this industry and to improve the productivity of human resources. With such support, the performance of the national TPT industry would be optimal, which leads to increased income and labor absorption. Other advantages will be delivered such as, reduced unemployment, rising consumer purchasing power, equalization, and eventually the national economic resilience.

\section{REFERENCES}

Akatiga and FES (2007), "Industri Tekstil dan Garmen Pasca ATC: Dimana Kita Berada?" Project Report, Akatiga and FES.

Brockimeier, M. (1996), "A Graphical Exposition of the GTAP Model,” GTAP Technical Paper 8, Center for Global Trade Analysis, Purdue University.

Central Bank of Indonesia (2012), "Butuh Kesiapan Menghadapi MEA 2015," Project Report, Bank Indonesia.

Fry, J., V. Honnold, B. Allen, R. Berry, L. Bloodgood, and S. Brady (2010), “ASEAN: Regional Trends in Economic Integration, Export Competitiveness, and Inbound Investment for Selected Industries," USITC Publication 4176, Investigation No. 332-511, United States International Trade Commission.

Hermawan, I. (2011), “Analisis Dampak Kebijakan Makroekonomi Terhadap Perkembangan Industri Tekstil dan Produk Tekstil Indonesia," Bulletin Ekonomi Moneter dan Perbankan, 13(4), 373-408.

Hertel, T.W. (eds.) (1997), Global Trade Analysis: Modeling and Applications, Cambridge University Press, New York.

Indonesia Investment Coordination Board (2011), "Kajian Pengembangan Industri Tekstil dan Produk Tekstil," Project Report, Badan Koordinasi Penanaman Modal.

Ministry of Industry (2011), "Kajian Pengembangan Industri Tekstil dan Produk Tekstil," Project Report, Kementerian Perdagangan Republik Indonesia

Ministry of Trade (2009), "Menuju ASEAN Economic Community," Project Report, Kementerian Perdagangan Republik Indonesia. 
Narayanan, S., G. Badri, B.V. Dimarananand and R.A. McDougall (2012), Guid to the GTAP Data Base in Global Trade, Assistance, and Production: The GTAP 8 Data Base, Center for Global Trade Analysis, Purdue University.

Rini, C.L. (2013, July, 9), "Ini Langkah Kemenperin Genjot Daya Saing Industri Tekstil," Republika.

Sari, N.J. (2013), "Daya Saing Industri Tekstil Tertekan," www.metrotvnews.com, accessed on 10 July 2013, 11.40 West Indonesian Time.

Susanto, I. (2013), "Kesiapan Industri TPT di Yogyakarta Menghadapi ASEAN Economic Community (AEC) 2015”, paper seminar on ISEI Jogjakarta, Asosiasi Pertekstilan Indonesia, Universitas Atmajaya Jogjakarta, SKH Kedaulatan Rakyat, 21 Agustus 2013.

Sutarta, A.E. (2001), "Evaluasi Manfaat Penghapusan Multi Fibre Arrangement (MFA) Dalam Putaran Uruguay Terhadap Perekonomian Indonesia," Unpublished Thesis, Gadjah Mada University.

Tambunan, T.T.H. (2013a), "Masyarakat Ekonomi ASEAN 2015: Peluang dan Tantangan Bagi UMKM Indonesia," Policy Paper, No. 5 March 2013, Chamber of Commerce of Indonesia and European Union, www.kadin-indonesia.or.id, accessed from on 9 July 2013, 12.30 west Indonesian time.

Tambunan, T.T.H. (2013b), "Kebijakan Industri Dalam Menyongsong ME-ASEAN 2015”, Policy Paper, No. 16 April 2013, Chamber of Commerce of Indonesia dan European Union, www.kadin-indonesia.or.id, accessed on 9 July 2013, 14.30 west Indonesian time. 